\title{
Cross Cultural Management in the Higher Educational Institutions
}

\author{
Tony S. Kuo \\ Shih Chien University, Taipei City, Taiwan
}

\begin{abstract}
The globalization has been leading to the inevitable interactions between people in business as well as in the higher education institutions from different cultures. The lack of cross-cultural communication skills often results in the misconception and misunderstanding, sometimes results in the unpleasant emotional and practical consequences. The increasing needs of internationalization among the higher education institutions raise the attention of cultural difference and the communicational skills. The understanding of crosscultural management in the higher education institutions is becoming necessary and important. The interactions between students to students and students to lecturers from different cultures reveal the significant differences in their values and attitudes or how they view and understand the world around them. This study is to show how a higher education institution is benefited from a better cross-cultural management through the comparisons from higher education institutions in different countries.
\end{abstract}

Keywords: cross culture, communication skill, cultural difference

\section{INTRODUCTION}

The globalization has been leading the inevitable interactions between people from different cultures for several decades. Those who learn the cross-cultural communication skills are benefited more from globalization and then tend to embrace more of it. Those who do not may lose the opportunity of gaining the value of globalization and tend to against it. The lack of cross-cultural communication skills often results in the misconception and misunderstanding, sometimes results in a wide variety of unpleasant emotional and practical consequences, from hurt feelings to failed negotiations and lost profits, and the worst, to hostility and conflicts. The cultural misunderstandings happen in real life. The knowledge of cross-cultural communication becomes more and more important. The increasing needs of internationalization among the higher education institutions all over the world raise the attention of cultural difference and the communicational skills. The teaching of cross-cultural management in the higher education institutions is becoming necessary and important. The interactions between students to students and students to lecturers from different cultures reveal the significant differences in their values and attitudes or how they view and understand the world around them. The speakers are not trying the express these differences, in fact, they are quite unaware of them, but the differences manifest themselves all the same as each speaker responds in a completely natural manner to the particular situation.

\section{DISCUSSIONS}

\subsection{Cross cultural management matters}

Higher education drives and is driven by globalization, a phenomenon of increasing worldwide interconnectedness that combines economic, cultural and social changes. Higher education trains the highly skilled workforce and contributes to the research and innovation capacity that increasingly determines competitiveness in the knowledge-based global economy. With its major role in cross-cultural encounters, higher education fosters mutual understanding and helps to build global networks for the future. At the same time, cross-border flows of ideas, students, lecturers, and finance, coupled with developments in information and communication technology, are changing the higher education environment. This implies both increased collaboration and competition between countries and institutions on a global scale. 
Will cross-border higher education - that is, the mobility of students, lecturers, programs, and institutions - continue to grow in the future? The growth in cross-border higher education has been one of the major trends in higher education over the past decades. Supported by the decline in transportation and communications costs and by programs actively geared to facilitating mobility within Europe and certain other countries, student mobility continues to grow apace with a $56 \%$ increase in the number of foreign students in the OECD area from 2000 to 2006. This increase has been accompanied by other, newer forms of mobility, international training mobility, and the mobility of higher education institutions, whether on a commercial or partnership basis.

Although the potential for growth in student mobility and training and institutional mobility does not yet seem to be over, different growth trajectories and futures scenarios can be considered. Given the cost and risks, institutional mobility may soon level off, especially as the market for training and foreign institutions appears to be quite limited geographically: countries like Singapore have assets that are attractive to cross-border higher education, but that are not present to the same extent in other countries. Furthermore, as long as internationalization is part of a capacity-building strategy in certain countries, it could take a different turn as these countries develop: student mobility in emerging countries such as China and India, which today tends to be for full study abroad, could, for example, begin to look more like the shorter-term mobility that is seen among OECD member countries.

The growing multi-cultural world makes culture is a powerful force and has to be properly understood. If we do not manage culture, then culture manages us without us knowing it. (Schein, 2012) Globalism means that works will increasingly be done by people from different nationalities, ethnicities, and religions. If they intend to work together, they must develop a common understanding of space, time, authority, human nature and the essence of human relationships. Complexity means that works will increasingly involve the meshing of expertise from different occupations. If they intend to work together, they must develop a common language, status system, rules of authority, and decision making. None of this will happen without good and clear teaching materials that give culture its due.

\subsection{Definitions of culture}

Finding a perfect definition of culture is actually not bringing much added-value to the debate. However, trying to find ways to reduce our natural tendency for ethnocentrism is worth the effort to ensure that we better comprehend the other and so reduce the tensions that lead to misunderstanding. The keys to a successful cross-cultural experience are to enhance your knowledge about a culture and your communication skills, learn a foreign language, and keep an open attitude towards the unexpected.

Every day we need skills to connect two apparently different situations: a problem and a solution or two conflicting ideas. Psychologists call this cognitive dissonance and it is absolutely common. Everyone is concerned; it is the human nature. (Dumetz 2012) Understanding cultures will teach people to respect the differences.

The explanation of cultures varies from country to country. Generally, the following definitions relate to the way people understand the reality of the world around them. This is associated with our understanding of culture related to civilization. The selected definitions of cultures: 1. "Culture is the collectively programming of the mind which distinguishes the members of one group from another." (Hofstede 1994). 2. "Culture is an integrated system of learned behavior patterns that are characteristic of the members of any given society. Culture refers to total way of life of a particular group of people. It includes everything that a group of people thinks, says, does, and makes, its customs, language, material artifacts, and shared system of attitudes and feelings. Culture is learned and transmitted from generation to generation." (Kohls 1984). 3. "Culture refers to whatever an identifiable group of people shares in order to meet its basic human needs and maintain its sense of identity." (Jean-Claude Arteau). 4. "Culture hides more than it reveals, and strangely enough, what it hides, it hides most effectively from its own participants." (Hall 1984). 5. "Culture is the way we solve problems."

\subsection{Stereotypes in culture}

When in contact with other cultures and whenever we face difficulties in comprehending or accepting the manners or habits of others, we have a common tendency to see the world through the prism of our own culture. Understanding other culture is not an easy process, and as human beings, we will often try to reduce the dissonance, by either denying the differences or by deciding their culture is simply better than the other. This behavior is called ethnocentrism and it is the prime obstacles to cross-cultural management (Dumetz 2012).

A stereotype is a cut-and-dried opinion. It is a result of categorization that guides our behavior, par- 
ticularly with regard to a given group or population of a given country. The stereotype never describes the behavior of an individual as it describes only the standard of the behavior that one allots to all the members of a given group.

Stereotypes are often negative but may also be positive. Indeed, they can be helpful as a starting point for understanding new situations. The key issue is not whether stereotypes are useful and dangerous but actually not to question them. Candidly questioning the validity of stereotypes gently leads to engaging discussions in a cross-cultural encounter. To avoid the damage caused by the stereotypes, the study of cross-cultural management is a recent discipline and the processes to quantify the capacity to adapt to foreign cultures are seldom. An original concept is Cultural Intelligence (CQ). Calculating $\mathrm{CQ}$ is an attempt to measure flexible and ready individuals are when confronted with a new culture.. Christopher Earley and Soon Ang (2003) identified three features of a person's cultural intelligence: Cognition, motivation, and behavior.

\subsection{Culture and communication}

Cross-cultural management is influenced by many sources, from religion to history, anthropology to sociology and business management, however, communication is a field which strongly affected by it. Management usually requires a communication skill. Therefore, it is often said that communication across cultures differs from place to place. Cultures become an issue when people interact with each other, what people do and say and how they do and say it is communication. Therefore, communication is everywhere so is culture. According to the research and accepted model (Shannon \& Weaver 1949), communication is all about sending messages to others. A person or the sender of the message, always need to choose several options when communicating with someone else. The message is coded into an accepted formal to fit the channel chosen. For the communication between several individuals to be complete, the receiver should send back some form of information or feedback to acknowledgment having the message. The feedback is essential in communication because only when you have the confirmation that your first message is understood or if you need to send a new message.

\section{CONCLUSIONS}

Cultural misunderstandings stem mostly from the different perception of a problem and lead to different solution proposals. In fact, higher education institutions are reaching out for student recruitment from other foreign countries. Recruiting a good number of students abroad can be done with a good strategy, such as granting scholarships and good programs. However, managing students from different cultures may acquire a good number of people willing to embrace students with different cultural backgrounds and having the sense of cross-cultural management. This study is to demonstrate that the quality of cross-cultural management in higher education institutions is the key to success of the internationalization of the higher education.

\section{REFERENCES}

Dumetz, J. 2012. Cross-Cultural Management Textbook. Charleston.

Hall, E.T. 1992. An Anthropology of Everyday Life. New York: Doubleday/Anchor Books.

Hofstede, G. 1994. Culture and Organization. Maidenhead: McGraw Hill.

Kohls, R. 1984. The values Americans Live By. Working paper. Washington DC: The Washington International Center

Schein, E.H. 2012. Corporate culture. Working paper. Cambridge MA: MIT Sloan School of Management

Shannon, C.E. \& Weaver, W. 1949. The mathematical theory of communication. Michigan: University of Illinois Press 